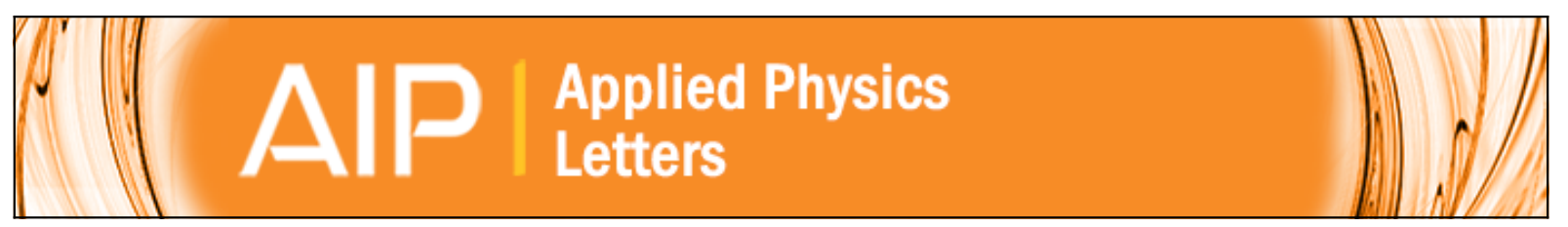

Micro-textures for efficient light trapping and improved electrical performance in thinfilm nanocrystalline silicon solar cells

Hairen Tan, Efthymia Psomadaki, Olindo Isabella, Marinus Fischer, Pavel Babal, Ravi Vasudevan, Miro Zeman, and Arno H. M. Smets

Citation: Applied Physics Letters 103, 173905 (2013); doi: 10.1063/1.4826639

View online: http://dx.doi.org/10.1063/1.4826639

View Table of Contents: http://scitation.aip.org/content/aip/journal/apl/103/17?ver=pdfcov

Published by the AIP Publishing

AlP 


\title{
Micro-textures for efficient light trapping and improved electrical performance in thin-film nanocrystalline silicon solar cells
}

\author{
Hairen Tan, ${ }^{\text {a) }}$ Efthymia Psomadaki, Olindo Isabella, Marinus Fischer, Pavel Babal, \\ Ravi Vasudevan, Miro Zeman, and Arno H. M. Smets ${ }^{a)}$ \\ Photovoltaic Materials and Devices Laboratory, Delft University of Technology, Mekelweg 4, Delft 2628CD, \\ The Netherlands
}

(Received 9 July 2013; accepted 2 October 2013; published online 23 October 2013)

\begin{abstract}
Micro-textures with large opening angles and smooth U-shape are applied to nanocrystalline silicon (nc-Si:H) solar cells. The micro-textured substrates result in higher open-circuit-voltage $\left(V_{o c}\right)$ and fill-factor $(F F)$ than nano-textured substrates. For thick solar cells, high $V_{o c}$ and $F F$ are maintained. Particularly, the $V_{o c}$ only drops from 564 to $541 \mathrm{mV}$ as solar cell thickness increases from 1 to $5 \mu \mathrm{m}$. The improvement in electrical performance of solar cells is ascribed to the growth of dense nc-Si:H layers free from defective filaments on micro-textured substrates. Thereby, micromorph tandem solar cells with an initial efficiency of $13.3 \%, V_{o c}=1.464 \mathrm{~V}$, and $F F=0.759$ are obtained. (C) 2013 AIP Publishing LLC. [http://dx.doi.org/10.1063/1.4826639]
\end{abstract}

Hydrogenated nanocrystalline silicon (nc-Si:H) is widely used as absorber layer in the bottom cell of multijunction thin-film silicon solar cells. ${ }^{1-5}$ The nano-textured substrates with morphology features in the order of $1 \mu \mathrm{m}$ are commonly used to achieve efficient light trapping in the state-of-the-art devices. ${ }^{4-10}$ However, the nano-textured substrates deteriorate the electrical performance of solar cells by decreasing the open-circuit voltage $\left(V_{o c}\right)$ and fill factor $(F F)$ compared to flat substrates. ${ }^{7,11,12}$ Furthermore, the $V_{o c}$ and $F F$ of nc-Si:H solar cells show considerable drop as the cell thickness increases, ${ }^{9,13-16}$ whilst thick nc-Si:H absorber layer (typically $2-3 \mu \mathrm{m}$ or even thicker) is required to achieve high current density. In addition, for economically viable nc$\mathrm{Si}: \mathrm{H}$ solar cells deposited at high deposition rates, the $V_{o c}$ and $F F$ are even more sensitive to the substrate textures and absorber layer thickness than the counterparts fabricated at low deposition rate. ${ }^{17-19}$

The decrease in $V_{o c}$ and $F F$ is commonly ascribed to the creation of porous and defective "cracks" in the absorber layer at concaves or sharp valleys. ${ }^{11,12}$ Here we use the term defective filaments to describe the physical nature of such porous and defective regions. The defective filaments are created at the sharp valleys even when the absorber layer is thinner than $1 \mu \mathrm{m} .{ }^{20}$ As the thickness increases, the defective filaments generate even on the smooth valleys. ${ }^{14}$ The deterioration of $V_{o c}$ and $F F$ in relatively thin cells can be partially mitigated by using substrates with smoother surface morphology (e.g., smooth U-shape instead of steep V-shape), ${ }^{15,20}$ by implementing silicon oxide-based $\left(\mathrm{SiO}_{x}: \mathrm{H}\right)$ doped layers, ${ }^{18,21,22}$ and by optimizing the plasma deposition conditions. ${ }^{18,23,24}$ However, it is still challenging to effectively maintain high $V_{o c}$ and $F F$ at thick absorber layers. Therefore, textured substrates which can provide efficient light trapping and maintain high $V_{o c}$ and $F F$ for thick absorber layers under high deposition rates are highly desirable.

Recently, Sai et al. have shown that periodically textured substrates with a large period resulted in higher short-

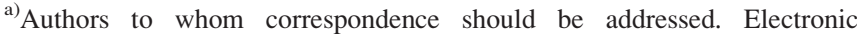
addresses: h.tan@tudelft.nl and a.h.m.smets@tudelft.nl.
}

circuit current density $\left(J_{s c}\right)$ and improved $V_{o c}$ and $F F$ in 3 - $\mu \mathrm{m}$-thick nc-Si:H solar cells compared to substrates with a small period. ${ }^{10,14}$ Their work suggests that substrates with an even larger period, which we here refer to as micro-textures (feature size $>5 \mu \mathrm{m}$ ), might have the potential to maintain high $V_{o c}$ and $F F$ in thick cells by growing nc-Si:H material free from defective filaments. In this letter, we explore the behavior of nc-Si:H solar cells deposited on the microtextured glass substrates.

Three different textured substrates as shown in Fig. 1 were studied: (i) nano-textured $\mathrm{ZnO}: \mathrm{Al}$ (AZO) on flat glass, (ii) micro-textured glass coated with as-deposited $\mathrm{ZnO}: \mathrm{Al}$, and (iii) modulated surface textured substrate by superposing nano-textured $\mathrm{ZnO}: \mathrm{Al}$ on micro-textured glass. For simplification in the following texts, we refer to these three substrates as EAZO, EG, and MST, respectively. The morphological properties obtained from AFM scans and haze in transmittance of the three substrates are summarized in Table I. The micro-textures on glass were generated by wetetching with $\mathrm{In}_{2} \mathrm{O}_{3}: \mathrm{Sn}$ as catalyst in a solution composing of $\mathrm{HF}$ and $\mathrm{H}_{2} \mathrm{O}_{2}$ for 30 min. ${ }^{25,26}$ The AZO layers $(1.5 \mu \mathrm{m}$ for EAZO and MST, and $1 \mu \mathrm{m}$ for EG) were fabricated by RF magnetron sputtering from a $\mathrm{ZnO}$ target with $2.0 \mathrm{wt}$ \% $\mathrm{Al}_{2} \mathrm{O}_{3}$. Nano-textured $\mathrm{AZO}$ was obtained by wet-etching in $0.5 \mathrm{wt} . \% \mathrm{HCl}$ for $40 \mathrm{~s}$. As shown in Fig. 1, the U-shaped craters in $\mathrm{EG}$ are much larger than the $\mathrm{V}$ - or $\mathrm{U}$-shaped craters in EAZO.

To evaluate the effects of the three different textures on the electrical performance and light trapping in solar cells, superstrate-type $p-i-n$ nc-Si:H solar cells $\left(4 \times 4 \mathrm{~mm}^{2}\right)$ were co-deposited on three substrates for each cell thickness using plasma-enhanced chemical vapor deposition (PECVD). The solar cells have a structure of $p-\mathrm{SiO}_{x}: \mathrm{H} / i-\mathrm{nc}-\mathrm{Si}: \mathrm{H} / n-\mathrm{SiO}_{x}: \mathrm{H} / \mathrm{Ag}$. The doped $\mathrm{SiO}_{x}: \mathrm{H}$ layers were deposited with RF-PECVD and kept the same in all devices. The i-layers were deposited at a rate of $\sim 40 \mathrm{~nm} / \mathrm{min}$ under high-pressure and high-power regime at $40.68 \mathrm{MHz}$, without any profiling or buffer layers. The $V_{o c}$ and $F F$ of solar cells were evaluated by current-voltage $(J-V)$ measurements with an AM $1.5 \mathrm{G}$ solar simulator $(100$ $\mathrm{mW} / \mathrm{cm}^{2}$ ) at $25^{\circ} \mathrm{C}$. The $J_{s c}$ values were calculated from the 
EAZO
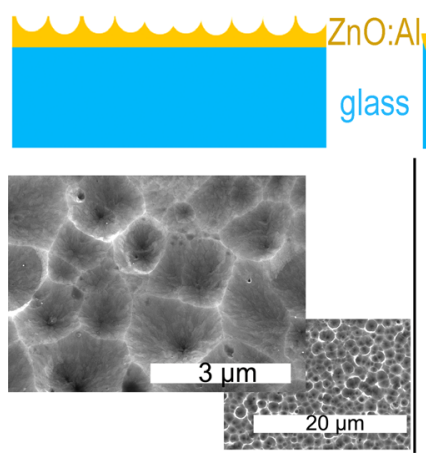

EG
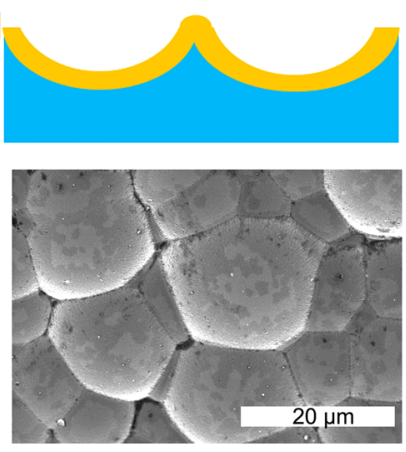

MST

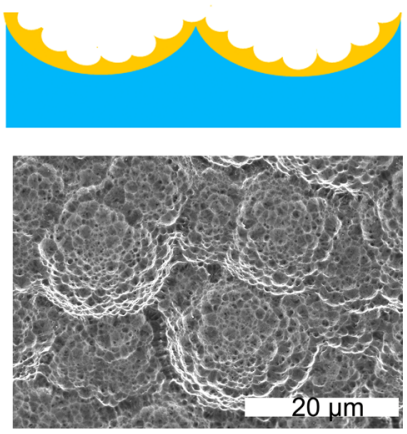

FIG. 1. Schematic structures and corresponding SEM images of nano-textured sputtered-etched AZO on flat glass (EAZO), micro-textured wet-etched glass covered by an asdeposited AZO layer (EG), and modulated surface textures superposing nano-textured AZO on microtextured glass (MST). external quantum efficiency (EQE) measurements, which exclude the overestimation of $J_{s c}$ due to the lateral current collection and any errors in the determination of active area of solar cells in $J-V$ measurements for small-area devices. ${ }^{1,10,14,27}$

Figure 2 summarizes the photovoltaic performance of nc-Si:H solar cells deposited on EG, EAZO, and MST. As the thickness of the i-layer $\left(t_{\mathrm{i}}\right)$ increases from 1 to $5 \mu \mathrm{m}$, the $V_{o c}$ and $F F$ decrease continuously for all the three substrates. However, the decreasing rate is different for the three textures. For cells deposited on EAZO, the $V_{o c}$ drops quickly from 558 to $487 \mathrm{mV}$ as $t_{\mathrm{i}}$ increases from 1 to $5 \mu \mathrm{m}$, which is consistent with previous experiments using nano-textured substrates. ${ }^{13-16}$ On the other hand, the $V_{o c}$ of cells deposited on EG drops by just $23 \mathrm{mV}$ as $t_{\mathrm{i}}$ increases from 1 to $5 \mu \mathrm{m}$, and it remains high for cells with $t_{\mathrm{i}}>2 \mu \mathrm{m}$ ( $V_{o c}$ of $551 \mathrm{mV}$ at $t_{\mathrm{i}}=3 \mu \mathrm{m}$ and $541 \mathrm{mV}$ at $\left.t_{\mathrm{i}}=5 \mu \mathrm{m}\right)$. The trend of the $F F$ with $t_{\mathrm{i}}$ for the three substrates is similar to the one seen in the $V_{o c}$. The FF of solar cells deposited on EG is higher than that of devices deposited on EAZO and MST for each thickness. Considering the $V_{o c} \times F F$ product, which is important for multi-junction solar cells, EG has higher values than EAZO and MST. The light trapping performance of the three substrates is indicated by the $J_{s c}$ values. As can been seen in Fig. 2, the EAZO and MST perform similarly as both have steep features from textured AZO layer which enable efficient light in-coupling. Note that only the EAZO used for $t_{i}=3 \mu \mathrm{m}$ was annealed at $400^{\circ} \mathrm{C}$ to reduce the free-carrierabsorption, ${ }^{28}$ and thus higher $J_{s c}$ than MST is expected. EG can provide relatively high $J_{s c}$ values when $t_{i}$ is above $2 \mu \mathrm{m}$. Overall, EAZO and MST are superior to EG from the point of light trapping capability. It should be noted that the $J_{s c}$ of cells deposited on EG continuously increases as $t_{i}$ increased from 1 to $5 \mu \mathrm{m}$, while for cells on EAZO and MST the $J_{s c}$ either drops or saturates for $t_{i}>3 \mu \mathrm{m}$.

When evaluating solar cells, the ultimate figure of merit is solar cell efficiency. For thin absorber layer $\left(t_{i}=1 \mu \mathrm{m}\right)$, EAZO and MST result in higher efficiency than EG, due to

TABLE I. Root-mean-square roughness $\left(r_{R M S}\right)$, correlation length $\left(L_{c}\right)$, aspect ratio $\left(r_{R M S}, L_{c}\right)$, and haze in transmittance at wavelength of $1000 \mathrm{~nm}$ $\left(H_{T} @ 1000 \mathrm{~nm}\right)$ of different substrates shown in Fig. 1.

\begin{tabular}{lcccc}
\hline \hline Substrate & $r_{R M S}(\mathrm{~nm})$ & $L_{c}(\mu \mathrm{m})$ & Aspect ratio & $H_{T} @ 1000 \mathrm{~nm}$ \\
\hline EAZO & 227 & 1.02 & 0.22 & 0.36 \\
EG & 889 & 5.10 & 0.17 & 0.84 \\
MST & 917 & 6.59 & 0.14 & 0.86 \\
\hline \hline
\end{tabular}

the better light trapping performance. This indicates that the micro-textures are not suitable for very thin nc-Si:H solar cells, as also indicated in Ref. 14. At $t_{i}=2 \mu \mathrm{m}$, the three substrates have almost the same efficiency $(\sim 9.5 \%)$. As the thickness increases further, the efficiency of solar cells deposited on EAZO and MST drops significantly due to the vastly decreasing $V_{o c}$ and $F F$. For cells deposited on EG, the highest efficiency $(10.0 \%)$ is obtained at $t_{i}=3 \mu \mathrm{m}$. Further increase of thickness results in slightly lower efficiency, possibly caused by the increased bulk recombination and resistance in the absorber layer, which leads to lower $F F$.

The solar cells performance is related with the density of defective filaments in the absorber layers. ${ }^{11}$ To check the presence of defective filaments in the nc-Si:H grown on the three different textures, cross-section images of solar cells were taken by a scanning electron microscopy (SEM, Hitachi S4800) with back scattering mode. As shown in Fig. 3 , the growth of nc-Si:H layer on EG is mostly conformal. The large U-shaped craters with large opening angles allow for the growth of dense nc-Si:H absorber layers free from defective filaments in the solar cells. The high device-quality material grown on EG results in the high $V_{o c}$ and $F F$ which holds true for both thin and thick devices, as shown in Fig. 2. On the contrary, for the nc-Si:H solar cells grown on EAZO or MST, the defective filaments (as indicated by the arrows) are clearly observed in the regions related to the sharp features. These defective filaments have detrimental effects on the electrical performance of solar cells. The porous defective filaments are shunt paths and significantly increase the leakage current (dark current), which reduces the $V_{o c}$ and $F F$ of solar cells. ${ }^{11}$ They also make solar cells more sensitive to the oxidization and in-diffusion of impurities into the i-layer, which further reduces the $V_{o c}, F F$, and the collection efficiency of photo-generated carriers. ${ }^{18}$ It is also observed that MST induces lower density of defective filaments than EAZO, which could explain that MST results in higher $V_{o c} \times F F$ product and higher $J_{s c}$ for thick absorber layers $\left(t_{i}>3 \mu \mathrm{m}\right)$ as shown in Fig. 2.

The $V_{o c}$ and $F F$ of nc-Si:H solar cells are also correlated with the crystallinity (volume fraction of the crystalline phase) of i-layer. ${ }^{29}$ Figure 4 shows the normalized Raman spectra and corresponding Raman crystallinity $\left(X_{c}\right)$ for solar cells deposited on different substrates. The $X_{c}$ is defined by $X_{c}=\left(I_{520}+I_{510}\right) /\left(I_{520}+I_{510}+0.8 \times I_{480}\right)$, where $I_{i}$ denotes the integration area under Gaussian fitting peak centered at $i$ $\mathrm{cm}^{-1}$. The measurements were done with a $633 \mathrm{~nm}$ laser 

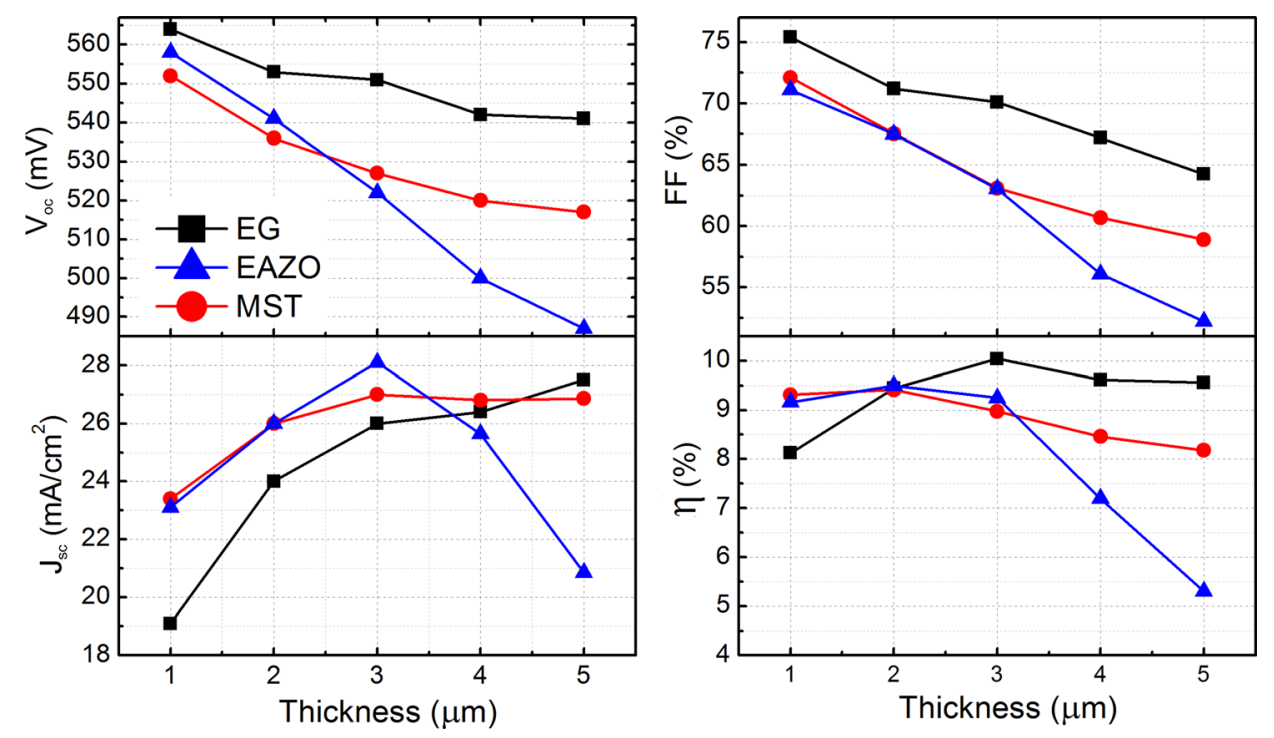

FIG. 2. Photovoltaic performance of single junction nc-Si:H solar cells deposited on EG, EAZO, and MST with different i-layer thickness. Note that the EAZO used for $t_{i}=3 \mu \mathrm{m}$ was annealed at $400^{\circ} \mathrm{C}$ to reduce the freecarrier-absorption, and thus higher $J_{s c}$ than MST is expected. from the $n$-side of the solar cells $\left(n-\mathrm{SiO}_{x}: \mathrm{H}\right.$ layers were removed by plasma etching before measurements) and the penetration depth is about $1 \mu \mathrm{m}$. As can be seen from Figs. 4(a) and 4(b), it seems that the three substrates result in almost the same crystallinity for a fixed i-layer thickness, indicating that the $V_{\mathrm{oc}}$ and $F F$ difference between different substrates is not related to crystallinity. Therefore, the nc-Si:H film quality dominantly affects the $V_{o c}$ and $F F$ of solar cells deposited on different substrates, considering that the deposition processing is the same for devices on different substrates. For the solar cells deposited on EG as shown in
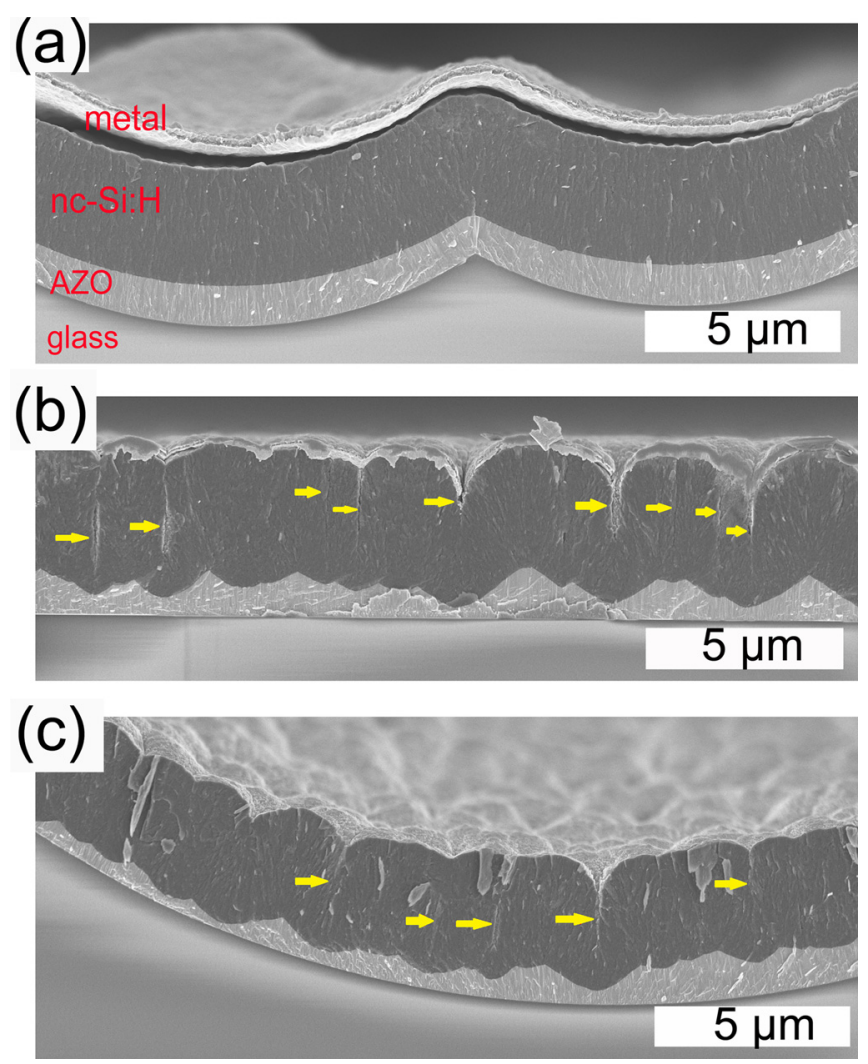

FIG. 3. Cross-sectional SEM images of nc-Si:H solar cells deposited on (a) EG, (b) EAZO, and (c) MST with i-layer thickness of $3 \mu \mathrm{m}$. The arrows indicate the defective filaments.
Fig. 4(c), the $X_{c}$ increases slightly as the i-layer grows thicker, which could partially explain the small drop of $V_{o c}$ for thicker i-layer. Optimizing the plasma deposition by $\mathrm{H}_{2}$ profiling or power profiling can further increase the $V_{o c}$ and $F F$ of solar cells by keeping the $X_{c}$ constant throughout the i-layer. $^{30,31}$

To evaluate the potential application of micro-textures in multi-junction solar cells, we deployed the three substrates in amorphous/nanocrystalline silicon (a-Si:H/nc-Si:H) tandem solar cells. We observed that tandem solar cells deposited on MST exhibits the same $J_{s c}$ as those on EAZO but have higher efficiency due to slightly higher $V_{o c}$ and $F F$. Therefore, in the following we only compare the performance of tandem cells deposited on EG and MST. Figure 5 shows the $J-V$ curves and the corresponding cross-sectional SEM images of devices deposited on EG and MST. Here, the top a-Si:H cells with a high $V_{o c}(\sim 950 \mathrm{mV}$ in a singlejunction cell) were used. The two cells were co-deposited and have a device structure of $p$-nc-Si:H/p-a-SiC:H/i-a-Si:H $(300 \mathrm{~nm}) / n$-a-Si:H/n-SiO${ }_{x}: \mathrm{H} / p-\mathrm{SiO}_{x}: \mathrm{H} / i$-nc-Si:H $(2.5 \mu \mathrm{m}) /$ $n-\mathrm{SiO}_{x}: \mathrm{H} / \mathrm{Ag}$. From Fig. 5(a) we can see that EG results in a significantly higher efficiency than MST. The $V_{o c}$ improves by $20 \mathrm{mV}$ which is mainly from the improvement in nc-Si:H bottom cell as indicated in Fig. 2, and the FF improves considerably from $73.1 \%$ to $75.9 \%$. It should be noted that the relatively high $F F(73.1 \%)$ for MST is due to the large current mismatch between the top and bottom cells, while the high $F F(75.9 \%)$ for EG is obtained under matched current condition. The significant improvement of the $V_{o c} \times F F$ product for EG is mainly ascribed to the better material quality of the nc-Si:H absorber layer deposited on EG. As shown in Figs. 5(b) and 5(c), the deposition on EG results in a dense nc-Si:H layer free from defective filaments, while on MST featuring nano-textures the defective filaments are observed in the nc-Si:H layer. The $J_{s c}$ of top cell on EG is higher than that on MST because of self nano-texturing of the as-deposited AZO layer on EG which can improve the light trapping in the a-Si:H top cell. The as-deposited AZO film has pyramidal growth fronts (as shown in the zoom-in image in Fig. 5(b)) and small RMS roughness of $\sim 17 \mathrm{~nm}$ (growth on flat glass), which is possibly due to that our $\mathrm{ZnO}$ : Al target 

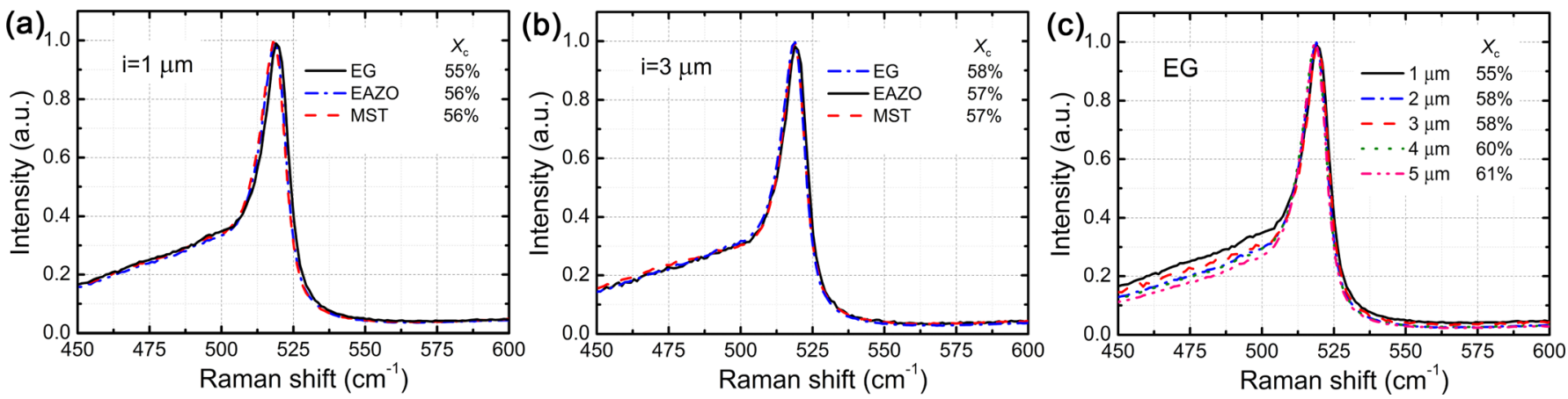

FIG. 4. Normalized Raman spectra of nc-Si:H solar cells deposited on EG, EAZO, and MST with i-layer thickness of (a) $1 \mu \mathrm{m}$, and (b) $3 \mu \mathrm{m}$. (c) Normalized Raman spectra of nc-Si:H solar cells deposited on EG with different i-layer thickness.
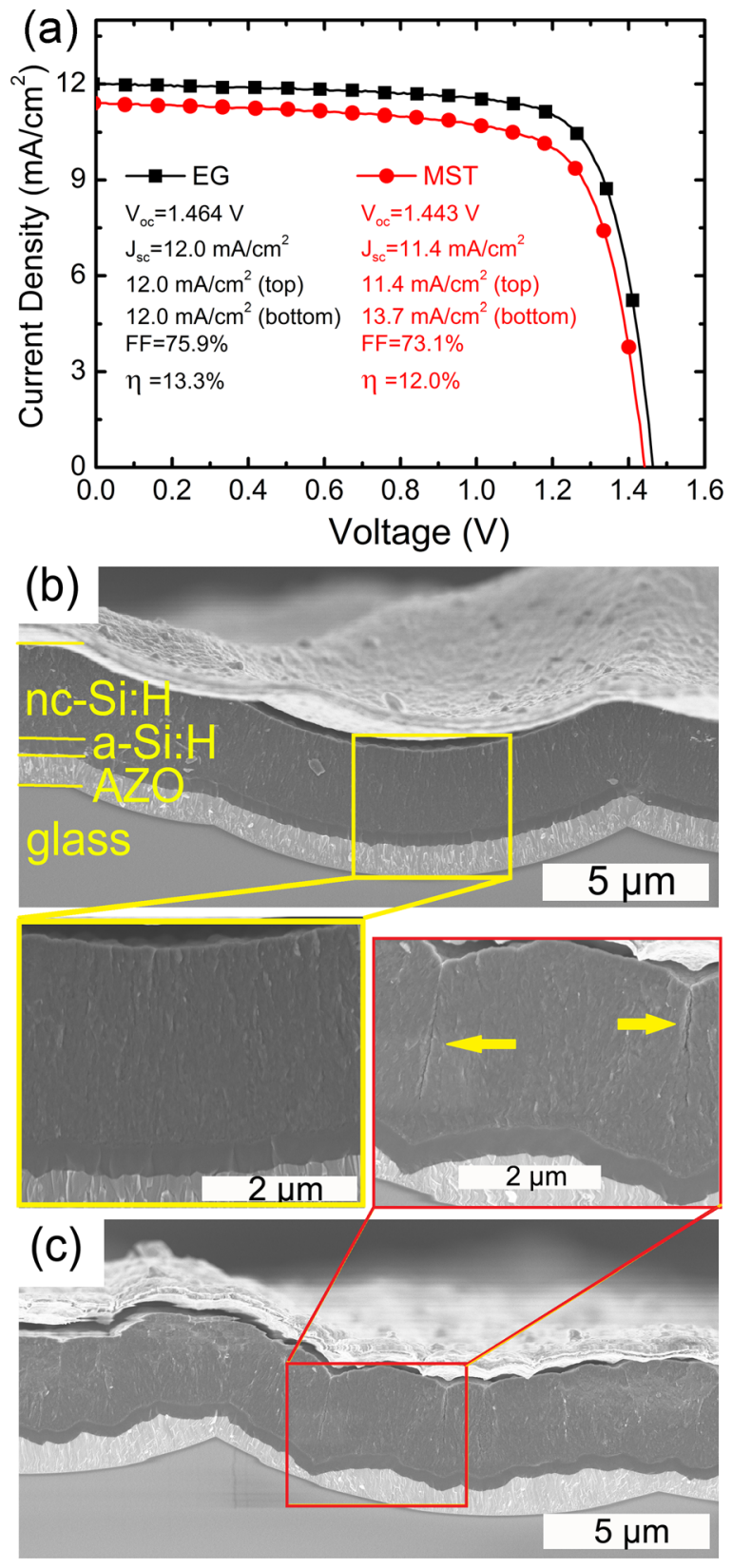

FIG. 5. (a) $J-V$ curves of a-Si:H/nc-Si:H tandem solar cells deposited on EG and MST. Reported $J_{s c}$ values of the top and bottom cells refer to the EQE measurements. Cross-sectional SEM images of tandem solar cells deposited on (b) EG and (c) MST. The arrows indicate the defective filaments. is oxygen-deficient. ${ }^{32}$ However, such small textures of the as-deposited $\mathrm{AZO}$ disappear after etching in $\mathrm{HCl}$ solution.

The $V_{o c} \times F F$ product $(1464 \times 0.759 \mathrm{mV})$ before lightsoaking is one of the highest reported values for highefficiency micromorph solar cells. This indicates the high potential of micro-textures for high efficiency multi-junction thin-film silicon solar cells. The limiting factor for EG is light scattering mainly into low angles with respect to the nano-textures, which makes it less efficient for light trapping. Higher aspect ratio micro-textures (here the aspect ratio of EG is only $0.15 \sim 0.20$ ) can significantly improve the light trapping in nc-Si:H bottom cells. ${ }^{10}$ Due to the large size and U-shape of micro-textures, the higher aspect ratio would not degrade the electrical performance of solar cells. Combining these on EG with the smooth and small nanotextures, which are suitable for light trapping in the a-Si:H top cell, $J_{s c}$ of the top cell can also increase which enables a thinner top a-Si:H cell and thus higher stabilized efficiency. The small nano-textures can be flattened again after the deposition of a-Si:H top cell, and thus will not affect the growth of the nc-Si:H bottom cell. ${ }^{5}$

To summarize, micro-textures can result in higher $V_{o c}$ and $F F$ than nano-textures in nc-Si:H solar cells. High $V_{o c}$ and $F F$ are maintained for thick devices. The $V_{o c}$ only drops from 564 to $541 \mathrm{mV}$ as i-layer thickness increases from 1 to $5 \mu \mathrm{m}$. The better electrical performance of nc-Si:H solar cells grown on micro-textures can be attributed to the improved material quality. The micro-textures with smooth U-shaped craters and large opening angels are advantageous for the growth of dense nc-Si:H layers free from the defective filaments. Finally, a-Si:H/nc-Si:H tandem solar cells deposited on micro-textured substrates exhibit an initial efficiency of $13.3 \%, V_{o c}=1.464 \mathrm{~V}$, and $F F=0.759$, indicating the high potential of micro-textures for high-efficiency multi-junction thin-film silicon solar cells.

The authors would like to thank Hozanna Miro for her useful help on the SEM measurements. Financial support from the Dutch STW-VIDI grant-10782 of Arno Smets is gratefully acknowledged.

${ }^{1}$ V. Shah, H. Schade, M. Vanecek, J. Meier, E. Vallat-Sauvain, N. Wyrsch, U. Kroll, C. Droz, and J. Bailat, Prog. Photovoltaics 12, 113 (2004).

${ }^{2}$ S. Guha, J. Yang, and Y. Bao, Sol. Energy Mater. Sol. Cells 119, 1-11 (2013). 
${ }^{3}$ S. Kim, J. Chung, H. Lee, J. Park, Y. Heo, and H. Lee, Sol. Energy Mater. Sol. Cells 119, 26-35 (2013).

${ }^{4}$ B. Yan, G. Yue, L. Sivec, J. Yang, S. Guha, and C. Jiang, Appl. Phys. Lett. 99, 113512 (2011).

${ }^{5}$ M. Boccard, C. Battaglia, S. Hanni, K. Soderstrom, J. Escarre, S. Nicolay, F. Meillaud, M. Despeisse, and C. Ballif, Nano Lett. 12, 1344 (2012).

${ }^{6}$ M. Berginski, J. Hüpkes, M. Schulte, G. Schöpe, H. Stiebig, B. Rech, and M. Wuttig, J. Appl. Phys. 101, 074903 (2007).

${ }^{7}$ B. Yan, G. Yue, L. Sivec, J. Owens-Mawson, J. Yang, and S. Guha, Sol. Energy Mater. Sol. Cells 104, 13 (2012).

${ }^{8}$ M. Zeman, O. Isabella, S. Solntsev, and K. Jäger, Sol. Energy Mater. Sol. Cells 119, 94-111 (2013).

${ }^{9}$ S. Hanni, G. Bugnon, G. Parascandolo, M. Boccard, J. Escarre, M. Despeisse, F. Meillaud, and C. Ballif, Prog. Photovoltaics 21, 821-826 (2013).

${ }^{10}$ H. Sai, K. Saito, and M. Kondo, Appl. Phys. Lett. 101, 173901 (2012).

${ }^{11}$ M. Python, E. Vallat-Sauvain, J. Bailat, D. Domine, L. Fesquet, A. Shah, and C. Ballif, J. Non-Cryst. Solids 354, 2258 (2008).

${ }^{12}$ Y. Nasuno, M. Kondo, and A. Matsuda, Jpn. J. Appl. Phys. Part 140 , L303 (2001).

${ }^{13}$ O. Vetterl, A. Lambertz, A. Dasgupta, F. Finger, B. Rech, O. Kluth, and H. Wagner, Sol. Energy Mater. Sol. Cells 66, 345 (2001).

${ }^{14}$ H. Sai, K. Saito, N. Hozuki, and M. Kondo, Appl. Phys. Lett. 102, 053509 (2013).

${ }^{15}$ M. Boccard, P. Cuony, M. Despeisse, D. Domine, A. Feltrin, N. Wyrsch, and C. Ballif, Sol. Energy Mater. Sol. Cells 95, 195 (2011).

${ }^{16}$ S. Hanni, D. Alexander, L. Ding, G. Bugnon, M. Boccard, C. Battaglia, P. Cuony, J. Escarre, G. Parascandolo, S. Nicolay, M. Cantoni, M. Despeisse, F. Meillaud, and C. Ballif, IEEE J. Photovoltaics 3, 11 (2013).

${ }^{17}$ A. Smets, T. Matsui, and M. Kondo, J. Appl. Phys. 104, 034508 (2008).
${ }^{18}$ G. Bugnon, G. Parascandolo, T. Soderstrom, P. Cuony, M. Despeisse, S. Hanni, J. Holovsky, F. Meillaud, and C. Ballif, Adv. Funct. Mater. 22, 3665 (2012).

${ }^{19}$ A. Gordijn, L. Hodakova, J. Rath, and R. Schropp, J. Non-Cryst. Solids 352, 1868 (2006).

${ }^{20}$ M. Python, O. Madani, D. Domine, F. Meillaud, E. Vallat-Sauvain, and C. Ballif, Sol. Energy Mater. Sol. Cells 93, 1714 (2009).

${ }^{21}$ P. Cuony, M. Marending, D. T. L. Alexander, M. Boccard, G. Bugnon, M. Despeisse, and C. Ballif, Appl. Phys. Lett. 97, 213502 (2010).

${ }^{22}$ M. Despeisse, C. Battaglia, M. Boccard, G. Bugnon, M. Charriere, P. Cuony, S. Hanni, L. Lofgren, F. Meillaud, G. Parascandolo, T. Soderstrom, and C. Ballif, Phys. Status Solidi A 208, 1863 (2011).

${ }^{23}$ S. Agbo, J. Krc, R. van Swaaij, and M. Zeman, Sol. Energy Mater. Sol. Cells 94, 1864 (2010).

${ }^{24}$ M. van den Donker, T. Kilper, D. Grunsky, B. Rech, L. Houben, W. Kessels, and M. van de Sanden, Thin Solid Films 515, 7455 (2007).

${ }^{25}$ O. Isabella, P. Liu, B. Bolman, J. Krc, and M. Zeman, in 2011 MRS Spring Meeting, edited by B. Yan (Mater. Res. Soc. Symp. Proc., 2011), Vol. 1321, p. 117.

${ }^{26}$ O. Isabella, F. Moll, J. Krc, and M. Zeman, Phys. Status Solidi A 207, 642 (2010).

${ }^{27}$ H. Tan, R. Santbergen, A. H. M. Smets, and M. Zeman, Nano Lett. 12, 4070 (2012).

${ }^{28}$ M. Wimmer, F. Ruske, S. Scherf, and B. Rech, Thin Solid Films 520, 4203 (2012).

${ }^{29}$ C. Droz, E. Vallat-Sauvain, J. Bailat, L. Feitknecht, J. Meier, and A. Shah, Sol. Energy Mater. Sol. Cells 81, 61 (2004).

${ }^{30}$ B. Yan, G. Yue, J. Yang, S. Guha, D. Williamson, D. Han, and C. Jiang, Appl. Phys. Lett. 85, 1955 (2004).

${ }^{31}$ X. Han, G. Hou, X. Zhang, C. Wei, G. Li, J. Zhang, X. Chen, D. Zhang, J. Sun, Y. Zhao, and X. Geng, Sol. Energy Mater. Sol. Cells 94, 254 (2010).

${ }^{32}$ D. Wan, F. Huang, Y. Wang, X. Mou, and F. Xu, ACS Appl. Mater. Interfaces 2, 2147 (2010). 